\title{
A retrospective analysis of outcome of pregnancy with acute renal failure during a period of one year at Geetanjali medical college \& hospitals, Udaipur, Rajasthan, India
}

\author{
Anjana Verma, Medhavi Sharma*
}

Department of Obstetrics \& Gynaecology, GMCH, Udaipur, Rajasthan, India

Received: 03 February 2016

Revised: 07 February 2016

Accepted: 03 March 2016

\section{*Correspondence:}

Dr. Medhavi Sharma,

E-mail: dr.medhavisharma23@gmail.com

Copyright: () the author(s), publisher and licensee Medip Academy. This is an open-access article distributed under the terms of the Creative Commons Attribution Non-Commercial License, which permits unrestricted non-commercial use, distribution, and reproduction in any medium, provided the original work is properly cited.

\begin{abstract}
Background: Acute kidney injury (AKI) is a life threatening complication of pregnancy. Pregnancy related Acute Renal Failure is usually a consequence of obstetric complication like pregnancy induced hypertension, pre eclampsia, eclampsia, septic abortion, HELLP, antepartum hemorrhage, and puerperal sepsis.

Methods: ARF was diagnosed when there was a history of sudden oliguria (urinary output $<400 \mathrm{ml}$ over $24 \mathrm{hrs}$ or less than $20 \mathrm{ml} /$ hour) or anuria with a sudden increase in serum creatinine to more than $1.5 \mathrm{mg} / \mathrm{dl}$ or an increase in serum creatinine of $>0.5 \mathrm{mg} / \mathrm{d} / /$ day from baseline. All patients with obstetrical ARF, antepartum as well as postpartum, were included in this study.

Results: From 256 patients, 15 patients (5.8\%) had pregnancy related ARF. Maternal outcome was assessed according to grading of AKI. The causes of ARF were pre eclampsia and eclampsia (40\%), HELLP (13.33\%), APH (13.33\%), PPH (20\%) and puerperal sepsis (6.66\%). Maternal mortality was 13.33\%. Neonatal outcome, amongst 14 patients, was noted and analyzed. Intrauterine deaths amongst them were 4/14 (28.57\%). Amongst 10 neonates which were admitted in neonatal ICU, 6/10 (60\%) survived and 4/10 (40\%) of them died.

Conclusions: Multidisciplinary services at tertiary level may reduce mortality due to Pregnancy related Acute Renal Failure. Most common etiological factor was pre eclampsia and eclampsia. Disappearance of illegal abortion, improvement in ANC with effective management of complicated pregnancy, the facility for safe early elective delivery whenever indicated, the improvement in resuscitation of obstetric hemorrhage and increased preparation of hospital birth had all contributed to the prevention of this devastating complication of pregnancy.
\end{abstract}

Keywords: Pregnancy related Acute renal failure, Acute kidney injury, Obstetric ARF

\section{INTRODUCTION}

Acute kidney injury (AKI) is a life threatening complication of pregnancy. Incidence of pregnancy related AKI has decreased, nearly $15-20 \%$ of AKI in India between 1970 and 1980 was attributable to obstetric complication. ${ }^{1}$ The current scenario of pregnancy related AKI in developed countries, is only $1-2.8 \%$. However, it is still frequent in developing countries, having incidence of $4.2-15 \% .^{2,3}$ The declining trend of Pregnancy related
AKI is attributed to legalization of termination of pregnancy and to better antenatal and postnatal care.

Acute tubular necrosis is the most common pathological lesion and has good prognosis as compared to other pathological lesions associated with DIC (Disseminated Intravascular Coagulation), HUS (Haemolytic Uremic Syndrome), severe eclampsia and HELLP syndrome (Haemolysis elevated liver enzymes and low platelet count) in which glomerular involvement is predominant. 
Acute bilateral renal cortical necrosis has the worst prognosis in obstetrically induced ARF which is mostly seen after APH and prolonged retention of dead fetus. Management of such patients require close monitoring and a multi-disciplinary approach and surveillance by obstetrician, nephrologist, gastroenterologist, neonatologist and anaesthesiologist.

Preeclampsia, eclampsia, HELLP, abruptio placentae manifest with acute intravascular volume depletion and severe reactive vasospasm which are responsible for decreased renal perfusion leading to AKI.

Severe hypovolemia results in decreased blood flow to renal cortex whereas perfusion to medullary area is preserved. Cortical ischemia results in marked decrease in GFR, concentrating ability and urinary volume. This stage of severe impairment in renal function is recognized as pre renal ARF. If cortical hypo perfusion occurs, or persists, functional changes are followed by ATN or cortical necrosis.

\section{METHODS}

This retrospective, observational study was conducted over a period of 1 year, in the Department of Obstetrics \& Gynaecology, Geetanjali Medical College \& Hospitals, Udaipur, Rajasthan, India. A total of 256 patients with ARF were admitted at the centre during the period. Out of these 15 patients had pregnancy related ARF and were included in our study.

ARF was diagnosed when there was a history of sudden oliguria ( urinary output $<400 \mathrm{ml}$ over $24 \mathrm{hrs}$. or less than $20 \mathrm{ml} /$ hour) or anuria with a sudden increase in serum creatinine to more than $1.5 \mathrm{mg} / \mathrm{dl}$ or an increase in serum creatinine of $>0.5 \mathrm{mg} / \mathrm{dl} /$ day from baseline. ${ }^{1}$

All patients with obstetrical ARF, antepartum as well as postpartum, were included in this study.

\section{Exclusion criteria}

1. Known renal disease prior to pregnancy (Glomerular Nephritis, Renal insufficiency from any cause)

2. History of hypertension / diabetes before gestation

3. History of renal stone diseases

4. History of NSAID abuse or analgesic nephropathy

5. Previous urological surgery

6. Renal scarring on USG

7. Small size of kidneys ( Small echogenic kidneys )

8. Elevated serum creatinine prior to gestation

9. History of reflux nephropathy

10. ESRD (End Stage Renal Disease)
Once enrolled for the study, complete obstetrical history including the details of antenatal care was taken. Thorough clinical examination and relevant investigations were performed. Patients were managed by a team of obstetricians, nephrologist, gastroenterologist, neonatologist \& interventionist.

Conservative treatment included all therapeutic modalities available as management of fluids, electrolytes, blood transfusion and antibiotics. Haemodialysis was done as a part of treatment wherever indicated. Complete recovery from ARF was declared when renal function returned to normal range. Cortical necrosis was diagnosed when patient remained anuric for $>3$ weeks and renal USG showed bilateral increased echogenicity with small sized kidneys and scattered renal cortical calcification and the patient remained dialysis dependent. All women were followed until they were discharged from hospital. Maternal outcome was recorded as complete recovery, partial recovery, dialysis dependent chronic kidney disease and death. Fetal outcome was recorded as survivors and non-survivors. Descriptive statistics were used in this study and percentages were calculated for qualitative variables like causes of ARF and outcome.

\section{RESULTS}

A total of $256 \mathrm{ARF}$ patients were observed at our institute for one year duration, of these 15 patients $(5.8 \%)$ had pregnancy related ARF which met the inclusion criterion and were enrolled in the study.

Table 1: Demographic profile of the patients.

\begin{tabular}{|ll|}
\hline AGE & $29.33 \pm 5.31$ \\
\hline Gestational age & $31.66 \pm 7$ \\
\hline Gravida & $1.66 \pm 1.21$ \\
\hline Parity & $1.26 \pm 0.924$ \\
\hline Primigravida (\%) & $3(20 \%)$ \\
\hline Multipara (\%) & $12(80 \%)$ \\
\hline Without ANC (\%) & $5(33.33 \%)$ \\
\hline Antepartum (\%) & $11(73.33 \%)$ \\
\hline Postpartum (\%) & $4(26.67 \%)$ \\
\hline Rural (\%) & $8(53.33 \%)$ \\
\hline Urban (\%) & $7(46.67 \%)$ \\
\hline Normal delivery (\%) & $10(66.67 \%)$ \\
\hline Caesarean section (\%) & $4(26.67 \%)$ \\
\hline $\begin{array}{l}\text { SERP (Surgical evacuation of } \\
\text { retained products of conception) }\end{array}$ & $1(6.67 \%)$ \\
\hline
\end{tabular}

The average age of onset for pregnancy related ARF is between 22-40 years, in our study mean age was $29.33 \pm 5.31$ years. In our study $3(20 \%)$ patients were primigravida and $12(80 \%)$ were multigravida. ARF occurred in $1(6.66 \%)$ patient in early half of their pregnancy and in $14(93.33 \%)$ patients in late pregnancy and puerperium. Out of these 14 patients $11(73.33 \%)$ 
were in antepartum period and $4(26.66 \%)$ were in postpartum period.

$7(46.67 \%)$ patients were the residents of urban area, $8(53.33 \%)$ of them were from rural background. Majority of patients, $10(66.66 \%)$ had received ANC and $5(33.33 \%)$ of them didn't received ANC at any stage of their pregnancy.

Table 2: Aetiology of pregnancy related ARF.

\begin{tabular}{|lll|}
\hline $\begin{array}{l}\text { Causes of ARF and } \\
\text { death in pregnancy }\end{array}$ & $\begin{array}{l}\text { Number } \\
(\mathrm{n})\end{array}$ & $\begin{array}{l}\text { Percentage } \\
\text { (In study) }\end{array}$ \\
\hline $\begin{array}{l}\text { Hypertensive disorder } \\
\text { Pre - eclampsia \& } \\
\text { eclampsia }\end{array}$ & 6 & $40 \%$ \\
\hline HELLP & 2 & $13.33 \%$ \\
\hline Hemorrhage & 2 & $13.33 \%$ \\
\hline APH & 3 & $20 \%$ \\
\hline PPH & 1 & $6.66 \%$ \\
\hline Uterine perforation $\left(2^{\text {nd }}\right.$ trimester $)$ & \\
\hline Puerperal sepsis & 1 & $6.66 \%$ \\
\hline DIC (late sequele) & 0 & \\
\hline
\end{tabular}

We noted a total of $10(71.4 \%)$ patients had vaginal delivery, all delivered at the hospital. 4(28.57\%) underwent caesarean section.

Table 3: Maternal outcome.

\begin{tabular}{|lllll|}
\hline \multicolumn{5}{c}{ Grading of AKI } \\
\hline $\begin{array}{l}\text { Survivors } \\
\text { Complete }\end{array}$ & 0 & 2 & 3 & Total \\
recovery & 1 & 1 & $2 / 10(20 \%)$ \\
\hline $\begin{array}{l}\text { Partial } \\
\text { recovery }\end{array}$ & 0 & 1 & 3 & $4 / 10(40 \%)$ \\
\hline $\begin{array}{l}\text { Dialysis } \\
\text { dependent }\end{array}$ & 1 & 0 & 3 & $4 / 10(40 \%)$ \\
\hline $\begin{array}{l}\text { Total } \\
\text { Non- } \\
\text { survivors }\end{array}$ & 0 & 0 & 2 & $2 / 15(13.33 \%)$ \\
\hline $\begin{array}{l}\text { LAMA } 3 \\
\text { (Left }\end{array}$ & 0 & 0 & 3 & $3 / 15(20 \%)$ \\
$\begin{array}{l}\text { against } \\
\text { medical } \\
\text { advice) }\end{array}$ & & & 7 & $10 / 15(66.66 \%)$ \\
\hline
\end{tabular}

Complete recovery of renal functions: Acute Tubular Necrosis \& Pre Renal Azotemia; Partial recovery of renal functions: Mild to Moderate Insufficiency; No recovery (dialysis dependent): Irreversible Bilateral Cortical Necrosis.

Main obstetric cause of pregnancy related ARF was hypertensive disorders of pregnancy (i.e. Preeclampsia/Eclampsia seen in $6(40 \%)$ patients and their sequele HELLP Syndrome in 2 patients (13.33\%), which was the most common etiological factor in the present study.
Table 3: Neonatal outcome.

\begin{tabular}{|lcl|}
\hline Parameters & $\mathrm{N}=4$ & $\%$ \\
\hline Intra-uterine death & 4 & $28.57 \%$ \\
\hline NICU(10) & & \\
\hline (a) Survivors & 6 & $42.85 \%$ \\
\hline (b) Non-survivors & 4 & $28.57 \%$ \\
\hline APGAR (Out of 6 fetal survivors) & \\
\hline Grade 1 (<5) & 3 & $50.00 \%$ \\
\hline Grade 2 (> 5 to <7) & 1 & $16.66 \%$ \\
\hline Grade 3 (7 to <9)) & 2 & $33.33 \%$ \\
\hline Total deaths & 8 & $57.14 \%$ \\
\hline (a) IUD & 4 & $28.57 \%$ \\
\hline (b) NICU Deaths & 4 & $40.00 \%$ \\
\hline
\end{tabular}

Obstetric hemorrhage due to Postpartum hemorrhage presented in 3 patients $(20 \%)$ and antepartum hemorrhage 2 patients (13.33\%). 1 patient underwent hemorrhage due to Uterine perforation.

Table 4: Acute kidney injury grade staging.

\begin{tabular}{|c|c|c|}
\hline $\begin{array}{l}\text { Grade of } \\
\text { AKI }\end{array}$ & $\begin{array}{l}\text { Serum } \\
\text { creatinine } \\
\text { criteria }\end{array}$ & Urine output \\
\hline 1 & $\begin{array}{l}\text { Serum creatinine } \\
\text { increase }> \\
0.3 \mathrm{mg} / \mathrm{dl} \\
\text { Or } \\
\text { Increase to } 1.5- \\
2.0 \text { fold from } \\
\text { baseline }\end{array}$ & $\begin{array}{l}<0.5 \mathrm{ml} / \mathrm{kg} / \mathrm{h} \text { for } \\
6 \mathrm{hrs}\end{array}$ \\
\hline 2 & $\begin{array}{l}\text { Serum creatinine } \\
\text { increase }>2.0- \\
3.0 \text { fold from } \\
\text { baseline }\end{array}$ & $\begin{array}{l}<0.5 \mathrm{ml} / \mathrm{kg} / \mathrm{h} \text { for } \\
12 \mathrm{hrs}\end{array}$ \\
\hline 3 & $\begin{array}{l}\text { Serum creatinine } \\
\text { increase }>3 \text { fold } \\
\text { from baseline } \\
\text { Or } \\
\text { Serum creatinine } \\
>4 \mathrm{mg} / \mathrm{dl} \text { with an } \\
\text { acute increase of } \\
\text { atleast } 0.5 \mathrm{mg} / \mathrm{dl} \\
\text { Or } \\
\text { Need for renal } \\
\text { replacement } \\
\text { therapy }\end{array}$ & $\begin{array}{l}<0.3 \mathrm{ml} / \mathrm{kg} / \mathrm{h} \text { for } \\
24 \mathrm{hrs} \\
\text { Or } \\
\text { Anuria for } 12 \mathrm{hrs} \\
\text { Or } \\
\text { Need for renal } \\
\text { replacement } \\
\text { therapy }\end{array}$ \\
\hline
\end{tabular}

In 1 patient Puerperal Sepsis was the etiological factor leading to ARF while DIC was the later sequele in some of the patients but not the primary cause.

Maternal morbidity and mortality is assessed according to grading of AKI. While managing patients with obstetric ARF, majority of patients required haemodialysis as renal replacement therapy. In the present study $8 / 15(53.33 \%)$ patients underwent haemodialysis, of them 3 patients left against medical advice, while $2 / 15(13.33 \%$ ) patients were 
treated conservatively and 2/15(13.33\%) patients were not able to survive. Recovery of renal function found in $6 / 10(60 \%)$, with complete recovery in $2 / 10(20 \%)$ patients. The majority of remaining patients $4 / 10(40 \%)$ had partial recovery and did not require renal replacement therapy. Percutaneous renal biopsy was done in 3 patients which showed diffuse glomerular capillary necrosis. Tubular necrotic changes seen in 2 specimens. One patient who had haemodialysis died due to acute tubular necrosis had immediate renal shutdown. One patient underwent MTP at 16-18 weeks.

Amongst 14 patients, neonatal outcome was noted and analysed. Intrauterine deaths amongst them were 4/14 $(28.57 \%)$. Amongst 10 neonates which were admitted in neonatal ICU, 6/10 (60\%) survived and 4/10 (40\%) of them died.

\section{DISCUSSION}

Acute renal failure due to obstetric cause has become rarer entity in developed countries $1-2.8 \% .^{6}$ In developing countries the incidence still remains $9-25 \%$, mainly due to late referral of pregnancy related to pregnancy related complications. $^{6}$ In the present study, the incidence is $5.8 \%$ which is similar to result found in other studies from India. $^{7-11}$ The reason of lower incidence in developed countries is prevention of pregnancy complications.

Abortion was the principal cause of ARF and a major health problem in developing countries in late seventies. ${ }^{8}$ However there was no case of septic abortion in our study. The proportion of ARF secondary to septic abortion has decreased from $33.8 \%$ to $1.8 \%$ over past 20 years, due to improved antenatal facilities. ${ }^{12}$ Its incidence could be reduced further by preventing unplanned pregnancies through increased use of regular contraception and use of emergency contraception.

Main obstetrical cause for ARF was hypertensive disorders of pregnancy (i.e. Pre-eclampsia/ Eclampsia seen in $6(40 \%)$ patients which was similar to the studies reported by other Indian authors (47.41\%) and $39.02 \% .^{13,14}$ Majority of studies have reported ecclampsia-pre-ecclampsia as a major cause of obstetric ARF in developed countries.

While managing patients with obstetric ARF, majority of patients required hemodialysis as renal replacement therapy. In the present study 8/15 (53.33\%) patients underwent hemodialysis, of them 3 patients left against medical advice, while 2/15 (13.33\%) patients were treated conservatively and $2 / 15(13.33 \%)$ patients were not able to survive, whereas similar study of 60 patients showed that $23(38.33 \%)$ patients required hemodialysis while rest 37 patients $(61.7 \%)$ were treated conservatively. ${ }^{1}$ In study by Najar MS hemodialysis was given to $32.5 \%$. $^{15}$
Total recovery of renal function found in 6/10 (60\%), with complete recovery in $2 / 10(20 \%)$ patients. The majority of remaining patients $4 / 10(40 \%)$ had partial recovery and did not require renal replacement therapy. Goplani et al reported a total recovery of renal function in $54.3 \% .^{5}$ Maternal outcome was recorded as complete recovery, partial recovery and dialysis dependent cases. One patient who had hemodialysis died due to acute tubular necrosis had immediate renal shutdown.

In our study maternal mortality was seen in one patient $(6.66 \%)$ while in similar studies it was $15 \%$ and $18.57 \%$ by other Indian authors. ${ }^{1,5}$

Perinatal mortality in the cases with Acute Renal Failure was observed in the cases of oliguric Acute Renal Failure. It was higher in those who had hypertensive disorder with acute renal failure. High rate of fetal death in our patients was perhaps a reflection of severity and number of insults occurring during pregnancy which not only resulted in fetal death but also caused severe renal failure which required dialysis. Eight in those who remained dialysis dependent and $6(75 \%)$ of those who recovered gave birth to alive baby. In a study conducted by Ali et al there was $45 \%$ fetal loss including $20 \%$ still birth and $40 \%$ live birth. ${ }^{16} 62 \%$ had live birth $31 \%$ had still birth in study done by Prakash et al. ${ }^{17}$ Celik et al reported that $19 \%$ had intrauterine death whereas in our study it was $4 / 10(28.57 \%){ }^{18}$

This analysis should provide useful guidelines for counselling women with pre-existing renal insufficiency about their prospects for a successful pregnancy and the effect of pregnancy on underlying disease.

\section{CONCLUSIONS}

Pregnancy related Acute Renal Failure is usually a consequence of obstetric complication. In our study, most common etiological factor was hypertensive disorders. . Prolonged duration of oliguria and hypertensive disorders was strong predictors of poor renal outcome and irreversible renal failure. Antenatal check-up helps in creating awareness among the pregnant mother and thus seek help from trained birth attendants thus should be done regularly.

\section{ACKNOWLEDGEMENTS}

An effort of Department of Medicine and Obstetrics \& Gynaecology, GMCH, Udaipur is being highly appreciated.

\author{
Funding: Not required \\ Conflict of interest: None declared \\ Ethical approval: The study was approved by the \\ Institutional Ethics Committee
}




\section{REFERENCES}

1. Patel M, Sachan R. Acute Renal Failure in pregnancy: tertiary centre experience from north Indian population. Nigerian Medical Journal. 2013;54:191-5.

2. Arrayhani M, El Youbi R, Sqalli T. Pregnancy related Acute Kidney Injury: Experience of the Nephrology Unit at the university hospital of Fez. Morocco. ISRN Nephrology 2013, Article ID 109034.

3. Kumar KS, Krishna CR, Kumar VS. Pregnancy related Acute Renal Failure. Journal of Obstetrics \& Gynaecology India. 2006;56:308-10.

4. Ricci Z, Cruz DN, Ronco C: Classification and staging of Acute Kidney Injury: Beyond RIFLE and AKIN Criterion. Nat Rev Nephrol. 2011;7(4):201-8.

5. Goplani KR, Shah PR, Gera DN. Pregnancy related Acute Renal Failure: A single-centre experience. Indian Journal of Nephrology. 2008;18(1):17-21.

6. Hassan I, Junejo AM. Etiology and outcome of Acute renal failure in pregnancy. Journal of the college of Physicians and Surgeons Pakistan 2009;19(11):714-7.

7. Pertuiset N, Grunfeld JP. Acute renal failure in pregnancy. Baillicres Clin Obstet Gynaecol. 1994;8:333-51.

8. Chugh KS, Sakhuja V, Malhotra HS, Pereira BJ. Changing trend in acute renal failure in third-world countries: Chandigarh study. Quart J Med. 1989;73(272):1117-23.

9. Mate-Kole MO, Yeboah ED, Affram RK, Ofori-Adjeji D, Adu D. Hemodialysis in the treatment of acute renal failure in tropical Africal: A 20-year review at the Korle $\mathrm{Bu}$ Teaching Hospital, Accra. Ren Fail. 1996;18:517-24.

10. Zewdu W. Acute renal failure in Addis Ababa, Ethopia: A prospective study of 136 patients. Ethopia Med J. 1994;32:79-87.
11. Naqvi R, Ahmed E, Akhter F, Yazdani I, Naqvi NZ, Rizvi A. Analysis of factors causing acute renal failure. J Pak Med Assoc. 1996;46:29-30.

12. Utas C, Yalcindag C, Taskapan H, Guven M, Oymak O, Yuceosy M. Acute renal failure in Central Anatolia. Nephrol Dial Transplant. 2000;15:152-5.

13. Sivakumar V, Sivaramakrishna G, Sainaresh VV, Sriramnaveen P, Kishore CK, Rani CS. Pregnancy-related acute renal: A ten- year experience. Saudi J Kidney Dis Transpl. 2011;22:352-3.

14. Kilari SK, Chinta RK, Vishnubhotla SK. Pregnancy related acute renal failure. J Obstet Gynecol India. 2006;56:308-10.

15. Najar MS, Shah AR, Wani LA, Reshi AR, Banday KA, Bhat MA, et al. Pregnancy related acute kidney injury: A single center experience from the Kashmir Valley. Indian J Nephrol. 2008;18:159-61.

16. Ali A, Zaffar S, Mehmood A, Nisar A. Obstetrical acute renal failure from Frontier Province: a 3 years prospective study. J Postgrad Med Inst. 2004;18:10917.

17. Prakash J, Vohra R, Wani IA, Murthy AS, Srivastava $\mathrm{PK}$, Tripathi K, et al. Decreasing incidence of renal cortical necrosis in patients with acute renal failure in developing countries: a single centre experience of 22 years from eastern India. Nephrol Dial Transplant. 2007;22:1213-7.

18. Celik C, Gezginc K, Altinepe L, Tonbul Z, Yaman ST, Akyurek C, et al. Results of the pregnancies with HELLP syndrome. Ren Fail. 2003;25:613-8.

Cite this article as: Verma A, Sharma M. A retrospective analysis of outcome of pregnancy with acute renal failure during a period of one year at Geetanjali medical college \& hospitals, Udaipur, Rajasthan, India. Int J Reprod Contracept Obstet Gynecol 2016;5:1140-4. 